\title{
T01 模型飛行機用スターリングエンジンの性能特性
}

\section{Performance Characteristics of Stirling Engine for Model Aircraft}

\author{
秋吉 保洋 (防衛大) 小平大輔 （防衛大） \\ 正 松口 淳 (防衛大) 正香川 澄 （防衛大） \\ 高山 秀雄
}

Yasuhiro Akiyoshi, National Defense Academy, 1-10-20 Hashirimizu, Yokosuka, 239-8686

Daisuke Odaira, National Defense Academy

Atsushi MATSUGUCHI, National Defense Academy

Noboru KAGAWA, National Defense Academy

Hideo Takayama

1 はじめに

スターリングエンジンは、作動流体を外部より加熱、冷却 することにより得られる圧力変動を利用して動力を得るエン ジンである。スターリングエンジンは外燃機関（連続燃焼） であり、爆発による燃焼行程が伴わないため、静肃性が非常 に高い。また、理論的に高い熱効率を持ち、多種類の燃料や 熱源を利用できるため、化石燃料を使用しない動力源として 利用できることから、近年の環境問題にも大きく貢献できる。

災害時等には、航空写真等、上空から得られる情報は非常 に有用である。しかし、この用途にしばしば利用されるへリ コプター等の飛行機は、その騒音が問題になることが多い。 この場合、静肃性、低然費という特性を有するスターリング エンジンを搭載した無人機を使用することは非常に有用であ ると考えられる。しかしながら、スターリングエンジンには 熱交換器が必要である(1)。その分エンジン質量が重くなって しまうため、飛行機に搭載するためには小型・軽量化する必 要がある。

スターリングエンジンの中でも $\beta$ 型スターリングェンジン は小型化に適していて、多くの模型スターリングエンジンに 採用されている。また、実用型エンジンとしても数 $\mathrm{kW}$ 以下 の小出カエンジンに採用されている。

2000 年、著者の 1 人である高山は $\beta$ 型スターリングエンジ ン $\beta 15.2000$ を搭載した模型飛行機を開発し,その試験飛行に 成功した (2)。本研究では $\beta 15$ - 2000 の基本性能の測定、得られ た測定結果等を基に、回転数と軸出力の関係、温度と軸出力 の関係を調べる。

\section{2 実験装置}

Fig. 1 に本研究に使用するスターリングエンジン $\beta$ 15 . 2000 の断面図を示す。Table. 1 に本エンジンの主要な緒元を示す。

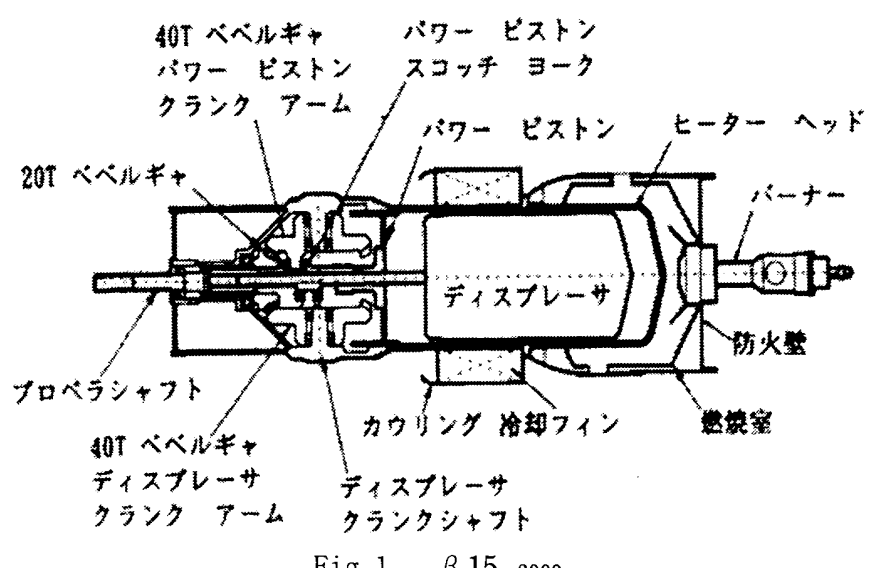

Table. 1 Specification of $\beta 15$.2000 Engine

\begin{tabular}{|l|l|}
\hline 基本形式 & $\beta$ 形式 ディスプレーサタイプ \\
\hline 全 長 & $196 \mathrm{~mm}$ (バーナーを含まず) \\
\hline 最大直径 & $\phi 57 \mathrm{~mm}$ \\
\hline 行程容積 & $15260 \mathrm{~mm}^{3}$ \\
\hline シリンダ直径 & $\phi 36 \mathrm{~mm}$ (パワーピストン、ディスプレーサ共) \\
\hline ストローク & $15 \mathrm{~mm}$ \\
\hline 位 相 角 & $63^{\circ} \mathrm{C}$ \\
\hline 作動空間 & 大気压 \\
\hline
\end{tabular}

本エンジンはプロペラシャフトとシリンダの軸心を一直 線に配し、1個のシリンダで賄うことができる $\beta$ 方式のエン ジンである。パワーピストンからクランク、クランクからデ イスプレーサの駆動は、エンジンの全長を短縮するためにス コッチヨーク機構による。

\section{3 測定方法}

本報告では、エンジンに取り付けたプロペラの回転数、ヒ 一ターヘッド部の温度、燃料流量を測定した。今回使用した 燃料は市販の液化ブタンカセットボンベである。

回転数の測定には非接触形回転計を用いた。非接触形回転 計から発した光を正確に受光させるために、プロペラのスピ ナー部に円盤を取り付け、そこに反射テープを張り付けて受 光部にした。

ヒーターヘッド部の温度は、燃焼室の排気口から熱電対を 插入し、ヒーターヘッドに接触させて測定した。また、燃料 消費量の測定については、プロペラの回転数を安定させ、ヒ ーターヘッド温度の測定を行ったのち、燃料を送るチューブ をエンジン本体から取り外し、水中においてメスシリンダー に 10 秒間入れ、捕集した量を測定した。

軸出力については測定によって得られた回転数から次式の 推定法 (3)を用いる。

$$
p=P \times D^{4} \times N^{3} \times 735.5 / 1.4 \times 10^{17} \cdot \cdot(1)
$$

ここで、 $p$ は出力 $(\mathrm{W}) 、 P$ はプロペラのピッチ（in）、Dはプ ロペラ值径（in）、Nはプロペラ回転数（rpm）である。

\section{4 結 果}

Fig. 2 に回転数とヒーターヘッド温度の関係を示す。図よ り、ヒーターヘッド温度を上昇させるにつれて回転数が上昇 し軸出力が増加していることがわかる。 


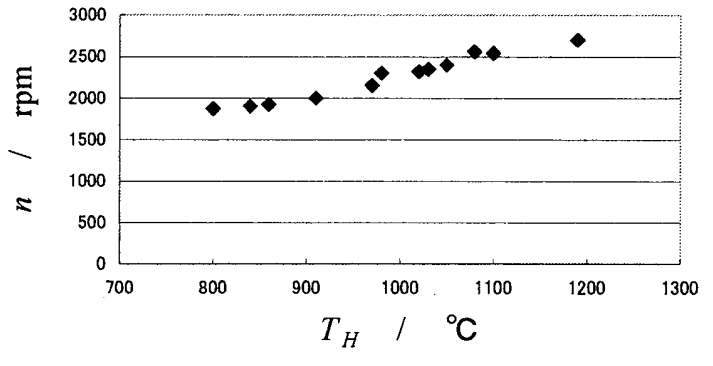

Fig.2 Heater-head temperature v.s. engine speed

Fig. 3 に測定した回転数毎の軸出力と、シュミットサイク ルを用いて計算し図示出力を示す。図示出力を求めるにあた って使用したシュミットサイクルの計算条件を Table. 2 に示 す。図より、回転数が増加するにあたり、軸出力が増加して いることが判明する。測定時における最大回転数は $2700 \mathrm{rmm}$ であった。この最大回転数は、高山 (2) が測定した最大回転 数と同等である。この実際の測定出力とシュミットサイクル による図示出力を比較すると、測定出力と図示出力では、そ の傾向が同様であり、このエンジンの軸出力は理想サイクル 出力の約 $40 \%$ 程度であることがわかる。

測定出力と図示出力の差の原因は、ヒーターヘッド部、バ 一ナ一部からの熱伝導損失、再生器損失、および、シリンダ 一・ディスプレーサ部、クランクケース内の摩擦等の機械損 失であると推定できる。したがって、断熱方法や再生器の改 良、空気予熱器の追加によって、軸出力は改善可能と考えら れるが、エンジン質量増加の原因ともなる。軸出力増加と質 量のバランスについては、今後の課題となろう。

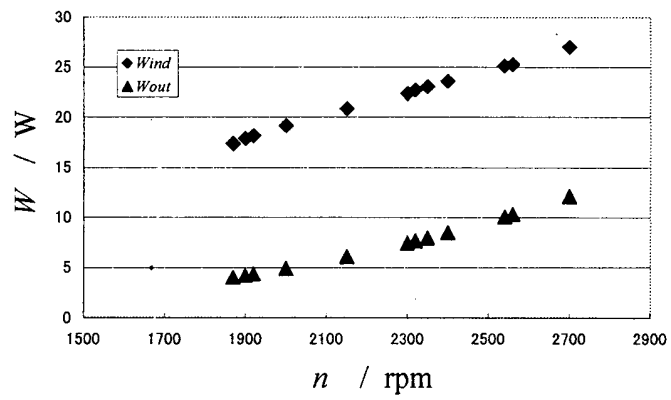

Fig.3 Relation with engine speed and output and indecated powers

Table. 2 Calculation condition for Schmidt cycle

\begin{tabular}{|l|l|}
\hline ディスプレーサ容積 & $15.26 \mathrm{~cm}^{3}$ \\
\hline パワーピストン容積 & $15.26 \mathrm{~cm}^{3}$ \\
\hline 再生器容積 & $0.034 \mathrm{~cm}^{3}$ \\
\hline 低温部温度 & $45^{\circ} \mathrm{C}$ \\
\hline 位相角度 & $63^{\circ}$ \\
\hline 作動空間圧力 & $0.1 \mathrm{MPa}$ \\
\hline
\end{tabular}

Fig. 4 に回転数と熱効率、軸出力の関係を示す。熱効率を 求める際に用いた式を以下に示す。

$$
\eta=\left\{W_{\text {out }} /\left(C \times H_{\ell}\right)\right\} \times 100
$$

ここで $\eta$ は熱効率 $(\%) 、 C$ は燃料消費量 $\left(\mathrm{Nm}^{3} / \mathrm{s}\right) 、 H_{\ell}$ は低発
熱量 $\left(\mathrm{kJ} / \mathrm{Nm}^{3}\right) 、 W_{\text {out }}$ は軸出力 $(\mathrm{W})$ である。

本測定に使用した燃料はブタンであり、その低位発熱量と して $118577 \mathrm{~kJ} / \mathrm{Nm}^{3}$ を用いた。図から回転数が上がるにつれ、 熱効率、軸出力が共に増加していることがわかる。

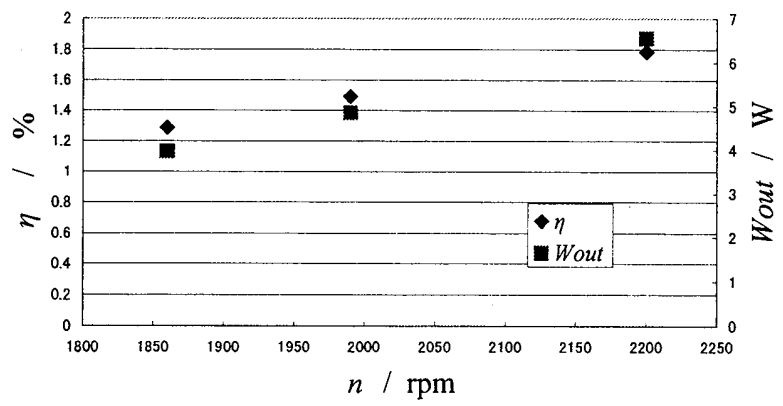

Fig.4 Thermal efficiency and output power

5 おわりに

$\beta 15$ 2000の基本性能の測定を行った結果、軸出力、熱効率 等のデータが得られた。模型エンジンは一般的に出力が小さ いため、精密な性能測定が非常に難しいと言われているが、 今後、様々なデータを得られるようにエンジン計測システム を構築していく。

今後の研究予定を以下に示す。

（1）エンジンの回転数を安定させ、燃料流量やトルク等、 エンジンの性能データを収集できる測定環境の整備

（2）回転数、ヒーターヘッド温度、低温部のいずれかを 一定にし、エンジン性能の測定

さらに、エンジンの性能の向上要素を探求していき、それら を $\beta 15$-2000に採用していきたい。

参考文献

（1）山下・他 4 名、山海堂、スターリングエンジンの理 論と設計、1999、4-12

（2）高山、第 5 回スターリングサイクルシンポジウム講 演論文集、2001、10.26、89-90

(3) G. Abbott、PROPELLERS、1986、132-133 